ISSN: $1412-8241$ (p); 2621-1246 (e), Volume 21. no (1) 2018

DOI: $10.22437 / j i s e b . v 21 i 1$

\title{
STRATEGI PENGEMBANGAN AGROINDUSTRI DODOL KENTANG LUBUK NAGODANG DI KABUPATEN KERINCI
}

\author{
Noli Putri Lika ${ }^{1)}$, Saad Murdy ${ }^{2)}$, Riri Oktari Ulma ${ }^{2)}$ \\ ${ }^{1)}$ Alumni Jurusan Agribisnis Program Studi Agribisnis Fakultas Pertanian Unja \\ ${ }^{2)}$ Staf Pengajar Jurusan Agribisnis Fakultas Pertanian Unja \\ Email : putrilikanoli@gmail.com
}

\begin{abstract}
ABSTRAK
Penelitian ini ditujukan untuk : 1) mengetahui besar biaya, penerimaan dan keuntungan usaha dari agroindustri dodol kentang Lubuk Nagodang di Kabupaten Kerinci, 2) mengetahui kondisi dan menentukan posisi agroindustri dodol kentang Lubuk Nagodang di Kabupaten Kerinci, 3) memformulasikan alternatif strategi yang dapat diterapkan oleh agroindustri dodol kentang Lubuk Nagodang di Kabupaten Kerinci. Penelitian ini dilaksanakan pada Tanggal 14-31 Juli 2016. Metode analisis data yang digunakan adalah analisis deskriptif dengan menggunakan analisis usaha dan analisis SWOT. Hasil penelitian menunjukkan bahwa : 1) biaya total agroindustri dodol kentang Lubuk Nagodang adalah sebesar Rp .2.238.615 dan penerimaan sebesar Rp. 5.864.000, sehingga keuntungan yang diperoleh pengrajin dodol kentang Lubuk Nagodang sebesar Rp. 3.625.385 per proses produksi, 2) identifikasi lingkungan agroindustri menunjukkan posisi agroindustri dodol kentang Lubuk Nagodang di Kabupaten Kerinci berada pada kuadran I dengan titik kuadran $(0,08 ; 0,14)$ mendukung kebijakan pertumbuhan agrresive, 3) alternatif strategi yang dapat diterapkan untuk memajukan agroindustri dodol kentang Lubuk Nagodang yaitu : a) bekerjasama dengan pemerintah dalam pengembangan agroindustri dodol kentang, b) meningkatkan kualitas, kuantitas dan memperluas pangsa pasar produksi dodol kentang Lubuk Nagodang melalui peningkatan kemampuan teknis tenaga kerja dan kerja sama dengan pemasok bahan baku kentang, c) memodifikasi kemasan untuk dapat meningkatkan daya tarik produk.
\end{abstract}

\section{Kata Kunci : Strategi Pengembangan, Dodol Kentang, Analisis Usaha, Analisis SWOT}

\begin{abstract}
This research was aimed to : 1) know cost, revenue and profit of "dodol kentang" agroindustry at Kerinci Regency, 2) know condition and determine position of "dodol kentang" Lubuk Nagodang agroindustry at Kerinci Regency, 3) formulate alternative strategies that could be implemented to improve of "dodol kentang" Lubuk Nagodang agroindustry at Kerinci Regency. This research was done on $14^{\text {th }}-31^{\text {st }}$ July,2016. The data on this reseacrh was analyzed descriptive methods by using business and SWOT analysis. The results of this research showed that : 1) the total cots of "dodol kentang" Lubuk Nagodang agroindustry was Rp. 2.238 .615 and the revenue was Rp. 5.864.000, so that profits to the onwer of "dodol kentang" Lubuk Nagodang was Rp. 3.625.385 per process of production, 2) identification of agroindustry environment at Kerinci Regency indicated that position of "dodol kentang" Lubuk Nagodang agroindustry at Kerinci Regency was at quadrant I $(0,08 ; 0,14)$ support a policy of agrresive growth, 3) the alternative strategies that could be done to improve of "dodol kentang" Lubuk Nagodang agroindustry were : a) making collaboration with Goverment development of "dodol kentang" Lubuk Nagodang agroindustri, b) increasing the quality, quantity and expanding the segment of market production of "dodol kentang" Lubuk Nagodang through improving technical ability of labor and doing collaboration with potatoes raw material suppliers, d) modifying the packaging to increasing product appel.
\end{abstract}

\section{Keywords: Strategy Development, Dodol Kentang, Business Analysis dan SWOT Analysis}




\section{JURNAL ILMIAH SOSIO-EKONOMIKA BISNIS}

ISSN: $1412-8241$ (p); 2621-1246 (e), Volume 21. no (1) 2018

DOI: $10.22437 / j i s e b . v 21 i 1$

\section{PENDAHULUAN}

Sektor pertanian di Indonesia masih memiliki banyak peluang dan prospek yang cerah serta belum digali. Meskipun pada masa sekarang sektor industri lebih diutamakan, perkembangan sektor pertanian tidak lepas sebagai pendukung yang kokoh, sehingga harus ada kerjasama antar bidang-bidang yang berkaitan. Salah satu sektor pertanian yang banyak dikembangkan pada sektor industri adalah pengolahan pangan atau dikenal agroindustri. Menurut Soekartawi (2001), agroindustri mampu meningkatkan nilai tambah produk pertanian, meningkatkan pendapatan para pelaku agribisnis, meningkatkan devisa dan mampu mendorong munculnya industri yang lain. Salah satu agroindustri yang ada di Kabupaten Kerinci adalah agroindustri dodol kentang Lubuk Nagodang yang pada saat ini menjadi produk unggulan daerah Kabupaten Kerinci. Agroindustri dodol kentang Lubuk Nagodang merupakan agroindustri yang mengelola makanan ringan khas Kabupaten Kerinci. Pemerintah merupakan salah satu yang berperan dalam pembentukan usaha ini, dimana melalui pemerintah pengrajin dodol kentang Lubuk Nagodang ini mendapatkan pelatihan-pelatihan dan pemahaman tentang mengelola usaha.

Desa Lubuk Nagodang merupakan sentra agroindustri dodol kentang Lubuk Nagodang di Kabupaten Kerinci. Selain dodol kentang Lubuk Nagodang Desa ini juga dikenal dengan usaha makanannya, seperti keripik kentang dan kerupuk kentang. Tujuan utama Pemerintah Kabupaten Kerinci melakukan pengembangan agroindustri ini adalah untuk meningkatkan pendapatan masyarakat di Desa Lubuk Nagodang Kecamatan Siulak Kabupaten Kerinci. Dodol kentang Lubuk Nagodang memiliki rasa yang khas dengan tanpa bahan pengawet. Agroindustri dodol kentang Lubuk Nagodang ini memiliki potensi dan prospek yang sangat baik untuk dikembangkan. Ditinjau dari aspek agroindustri, agroindustri dodol kentang Lubuk Nagodang pada umumnya masih bersifat industri padat karya yaitu industri yang lebih dititik beratkan pada sejumlah besar tenaga kerja atau pekerja dalam pengolahannya yang dijalankan dengan teknologi sederhana. Hal tersebut merupakan kendala utama dalam upaya pengembangan dodol kentang Lubuk Nagodang menjadi industri madya ataupun industri modern yaitu industri dalam pengolahannya menggunakan teknologi modern, dari segi teknologi agroindustri ini masih memiliki kelemahan tidak adanya teknologi yang digunakan untuk pengemasan masih menggunakan teknologi manual. Kurangnya kreatifitas pengrajin dalam mengolah dodol kentang Lubuk Nagodang merupakan kendala kedua dalam upaya pengembangan dodol kentang Lubuk Nagodang yaitu ketahanan produk relatif singkat, walaupun pada saat ini telah memiliki berbagai varian rasa seperti rasa pandan, gula aren, durian, nangka, nanas, strawberry, dan lainnya, namun dari segi ketahan masih relatif singkat. Hal ini dikarenakan dodol kentang Lubuk Nagodang tidak menggunakan bahan pengawet. Oleh sebab itu, bahan baku, bahan penolong, proses pemasakan dan penjemuran dodol kentang Lubuk Nagodang sangat berpengaruh terhadap ketahanan produk.

Ditinjau dari sisi Product Life Cycle (PLC) yang merupakan suatu hal yang penting bagi setiap produsen untuk memproduksi dan memasarkan produknya. Posisi produk dodol kentang Lubuk Nagodang dapat diidentifikasi melalui tahapan PLC dilihat dari market volume, rate of change of market volume, dan profit/loss pada agroindustri tersebut (Tjipjono, 2002). Jika dilihat dari sisi usia usaha 18 tahun dimana agroindustri ini dapat dinilai bahwa telah mampu mempertahankan posisi pada daur hidup produk di tahap pertumbuhan, namun pada kenyataannya agroindustri dodol kentang Lubuk Nagodang pada saat ini menuju tahap II yaitu tahap pertumbuhan dan telah melewati tahan I yaitu tahap perkenalan dimana adanya promosi yang dilakukan oleh Dinas Perindustrian, Perdagangan dan ESDM di Kabupaten Kerinci pada acara besar Kabupaten Kerinci, tetapi 


\section{JURNAL ILMIAH SOSIO-EKONOMIKA BISNIS}

ISSN: 1412-8241 (p); 2621-1246 (e), Volume 21. no (1) 2018

DOI: $10.22437 / j i s e b . v 21 i 1$

dari pihak agroindustri kurang melakukan kegiatan promosi. Tahap II (tahap petumbuhan) yaitu tahap dimana suatu periode penerimaan pasar yang cepat dan peningkatan laba yang besar oleh agroindustri dodol kentang Lubuk Nagodang serta distribusi produk dodol kentang Lubuk Nagodang telah keluar daerah Kabupaten Kerinci namun distribusi masih perlu perluasan jangkauan pangsa pasar. Pada agroindustri dodol kentang Lubuk Nagodang untuk tetap berada pada tahap pertumbuhan agroindustri ini masih memiliki kelemahan yaitu dari segi keterbatasan teknologi untuk memodifikasi kemasan, belum memiliki sistem manajemen yang baik serta memperbanyak saluran distribusi dan memperluas cakupan distribusi, dalam perkembangannya agroindustri ini menghadapi berbagai ancaman diantaranya yaitu munculnya agroindustri pesaing produk sejenis dan pesaing produk substitusi.

Agar usaha agroindustri dodol kentang Lubuk Nagodang dapat terus bertahan dan berkembang, maka dibutuhkan strategi-strategi yang disusun untuk memperlihatkan lingkungan internal dan lingkungan eksternal dari perusahaan tersebut. Strategi pengembangan produk memiliki peranan penting dalam keberlangsungan usaha. Karena pada dasarnya suatu perusahaan baru akan mencapai tujuannya apabila produk yang dihasilkan dapat diterima oleh konsumen atau pasar. Dalam upaya pengembangan dodol kentang Lubuk Nagodang yang berkelanjutan, maka diperlukan suatu analisis usaha untuk melihat bagaimana biaya, penerimaan dan keuntungan dalam pengembangan agroindustri serta analisis situasi untuk menentukan posisi keberadaannya dengan analisis kondisi suatu perusahaan dengan memaksimalkan kekuatan dan peluang yang ada, namun meminimalkan kelemahan dan ancaman, sehingga didapat alternatif-alternatif strategi dalam pengembangan agroindustri dodol kentang Lubuk Nagodang di Kabupaten Kerinci.

Berdasarkan latar belakang dan permasalahan yang dikemukakan, maka penelitian ini bertujuan : 1) untuk mengetahui besarnya biaya, penerimaan, dan keuntungan usaha dari agroindustri dodol kentang Lubuk Nagodang Lubuk Nagodang di Kabupaten Kerinci, 2) untuk mengetahui kondisi dan menentukan posisi agroindustri dodol Lubuk Nagodang kentang di Kabupaten Kerinci, 3) ntuk memformulasikan alternatif strategi yang dapat diterapkan oleh pihak Agroindustri dodol kentang Lubuk Nagodang Lubuk Nagodang.

\section{METODE PENELITIAN}

Penelitian ini dilaksanakan di Kabupaten Kerinci yaitu di Desa Lubuk Nagodang Kecamatan Siulak dimana penentuan lokasi berdasarkan informasi dari Dinas Perindustrian, Perdagangan dan ESDM Kabupaten Kerinci, yang diambil secara sengaja (purposive). Hal ini dilakukan atas dasar bahwa produk unggulan daerah yang merupakan satu-satunya sentra produksi agroindustri dodol kentang Lubuk Nagodang di Kabupaten Kerinci. Objek penelitian ini adalah pengrajin Agroindustri Dodol kentang Lubuk Nagodang. Untuk menentukan jumlah sampel dalam penelitian ini dilakukan melalui Purposive Sampling yaitu dengan cara Judgment Sampling, dimana penarikan sampel yang dilakukan berdasarkan penelitian terhadap karakteristik anggota sampel sesuai dengan tujuan yakni penarikan sampel dilihat dari agroindustri aktif yang lama usaha lebih dari 15 tahun alasan menentukan skala jumlah produk yang dihasilkan, 7 unit usaha yang menjadi responden pada penelitian ini. Analisis data yang digunakan adalah deskriptif dengan analisi usaha dan analisis SWOT. Analisis usaha yang terdiri dari biaya, peneriamaan dan keuntungan. Secara umum rumus biaya total (Sukirno, 2015) adalah:

$\mathrm{TC}=\mathrm{TFC}+\mathrm{TVC}$

Keterangan

TC = biaya total agroindustri dodol kentang Lubuk Nagodang (Rp/produksi)

$\mathrm{TFC}=$ total biaya tetap agroindustri dodol kentang Lubuk Nagodang (Rp/produksi) 


\section{JURNAL ILMIAH SOSIO-EKONOMIKA BISNIS}

ISSN: 1412-8241 (p); 2621-1246 (e), Volume 21. no (1) 2018

DOI: 10.22437 jiseb.v21i1

TVC = total biaya variabel agroindustri dodol kentang Lubuk Nagodang (Rp/produksi)

Menurut Soekartawi (2005) penerimaan adalah hasil perkalian antara produksi yang diperoleh dengan harga jual. Pernyataan tersebut dapat dituis dalam bentuk persamaan sebagai berikut :

$$
\mathrm{TR}=\mathrm{Q} \times \mathrm{P}
$$

\section{Keterangan :}

$\mathrm{TR}=$ penerimaan total agroindustri dodol kentang Lubuk Nagodang (Rp/produksi)

$\mathrm{Q} \quad$ = jumlah produk agroindustri dodol kentang Lubuk Nagodang (Ktk/produksi)

$\mathrm{P} \quad$ = harga produk agroindustri dodol kentang Lubuk Nagodang (Rp/produksi)

Menurut Soekartawi (2005), keuntungan adalah selisih penerimaan total dan biayabiaya. Secara sistematis dapat dirumuskan sebagai beriku.

$\Pi=T R-T C$

Keterngan

$\pi \quad=$ keuntungan agroindustri dodol kentang Lubuk Nagodang (Rp/produksi)

$\mathrm{TR}$ = penerimaan total agroindustri dodol kentang Lubuk Nagodang (Rp/produksi)

TC = biaya total agroindustri dodol kentang Lubuk Nagodang (Rp/produksi)

Menurut Rangkuti (2015) analisis SWOTyakni metode untuk identifikasi berbagai faktor secara sistematis untuk merumuskan strategi yang diperlukan. Analisis SWOT dilakukan dalam tiga tahap, yaitu : 1) identifikasi Faktor Lingkungan Internal dan Faktor Lingkungan Eksternal, yang bertujuan untuk menggambarkan bagaimana kondisi dari lingkungan internal dan lingkungan eksternal dari agroindustri dodol kentang Lubuk Nagodang. 2) matrik IFAS dan EFAS yang bertujuan untuk menentukan posisi. Tahap-tahap yang diakukan dalam penentuan posisi agroindustri dodol kentang Lubuk Nagodang adalah sebagai berikut : a). Penentuan bobot setiap skala faktor mulai dari 0,0 (tidak penting) sampai 1,0 (paling penting). Penentuan bobot dijalankan mengajukan identifikasi faktor strategis internal dan strategis eksternal dengan menggunakan metode paired comparasion. Untuk menentukan bobot setiab variabel digunakan skala 1, 2, dan 3 yang digunakan dalam pengisian kolom. Bobot setiap variabel diperoleh dengan menentukan nilai setiap variabel terhadap jumlah nilai keseluruhan variabel dengan menggunakan rumus Kinner and Taylor (1991) dalam siholoh (2009) sebagai berikut :

Keterangan :

$$
\alpha_{i}=\frac{X_{i}}{\sum_{i=1}^{n} X_{i}}
$$

$\alpha_{i}=$ Bobot variabel ke-i

$X_{i}=$ Nilal variabel ke-i

$n=$ Jumlah variabel

$i=1,2,3 \ldots \ldots . n$

b). Penentuan rating, penentuan rating pada agroindustri dodol kentang Lubuk Nagodang dilakukandengan menggunakan kuesioner. Responden yang melakukan penilaian adalah pihak pemerintah dan pemilik mini market di Kabupaten Kerinci. Untuk pemberian rating masing-masing faktor dengan memberikan skala mulai dari 4 (outstanding) sampa 1 (poor). Pemberian nilai rating untuk faktor IFAS kekuatan dimulai dari angka 4 (bersifat positif) sampai 1 (bersifat negatif) sedangkan kelemahan kebalikannya. Rating untuk EFAS faktor peluang dimulai dari angka 4 (bersifat positif) sampai 1 (bersifat negatif) sedangkan ancaman kebalikannya. Rating 1-4 ditentukan dengan membandingkan fakta dengan kinerja ideal yang diinginkan agroindustri. Hal ini dilakukan karena pada penelitian ini faktor strategi internal dan eksternal yang telah diidentifikasi sebelumnya tidak ada nilai pembanding untuk memberi bobot. Kemudian nilai yang didapatkan dari matrik IFAS dan matrik EFAS ini digabungkan untuk menentukan posisi pengembangan usaha pada diagram analisis SWOT dan selanjutnya dapat menentukan alternatif strategi yang dapat dilakukan 


\section{JURNAL ILMIAH SOSIO-EKONOMIKA BISNIS}

ISSN: $1412-8241$ (p); 2621-1246 (e), Volume 21. no (1) 2018

DOI: $10.22437 / j i s e b . v 21 i 1$

dalam rangka pengembangan agroindustri dodol kentang Lubuk Nagodang, 3) Matriks SWOT. Matrik SWOT merupakan alat pencocokan yang penting untuk membantu dalam mengembangkan empat tipe strategi, yakni a). Strategi SO yaitu strategi yang menggunakan kekuatan internal untuk memanfaatkan peluang eksternal, b). Strategi WO yaitu strategi yang bertujuan untuk memperbaiki kelemahan internal dengan memanfaatkan peluang eksternal, c). Strategi ST yaitu strategi yang menggunakan kekuatan internal untuk menghindari ancaman eksternal serta, d). Strategi WT merupakan strategi yang diarahkan untuk mengurangi kelemahan internal dan menghindari ancaman eksternal.

\section{HASIL DAN PEMBAHASAN}

\section{Analisis Usaha}

Biaya produksi adalah nilai dari semua faktor produksi yang digunakan, baik dalam bentuk benda maupun jasa selama proses produksi berlangsung. Biaya produksi yang digunakan terdiri dari sewa lokasi, bunga modal, biaya sarana produksi serta biaya tenaga kerja (Soekartawi, 2005). Biaya total merupakan hasil penjumlahan seluruh biaya tetap dan biaya variabel yang dikeluarkan dalam satu kali produksi. Dalam penelitian ini biaya total terdiri dari biaya tetap dan biaya variabel. Berdasarkan hasil penelitian pada agroindustri dodol kentang Lubuk Nagodang di Kabupaten Kerinci biaya tetap merupakan biaya yang digunakan dalam usaha agroindustri dodol kentang Lubuk Nagodang yang besarnya tidak dipengaruhi oleh jumlah produksi dodol kentang Lubuk Nagodang, yang meliputi biaya penyusutan peralatan. Biaya penyusutan adalan biaya yang sebenarnya benar-benar dikeluarkan oleh pengrajin dodol kentang Lubuk Nagodang dan bukan berupa bantuan. Biaya variabel merupakan biaya yang digunakan dalam proses produksi dodol kentang Lubuk Nagodang yang besarnya berubah-ubah secara proposioanal terhadap kuantitas ouput yang yang dihasilnya. Adapun besar rata-rata biaya total yang dihasilkan dapat dilihat pada Tabel 1.

Tabel 1. Rata-rata Biaya Total Usaha Agroindustri Dodol kentang Lubuk Nagodang di Kabupaten Kerinci Dalam Satu Kali Produksi

\begin{tabular}{clrr}
\hline No & Jenis Biaya Total & Rata-Rata & Persentase (\%) \\
\hline 1 & Biaya Tetap & 5.580 & 0,25 \\
2 & Biaya Variabel & 2.233 .035 & 99,75 \\
\hline & Total & $\mathbf{2 . 2 3 8 . 6 1 5}$ & $\mathbf{1 0 0}$ \\
\hline
\end{tabular}

Berdasarkan hasil penelitian pada agroindustri dodol kentang Lubuk Nagodang di Kabupaten Kerinci bahwa rata-rata biaya total yang dikeluarkan dalam satu kali produksi adalah sebesar Rp. 2.238.615. Biaya terbesar yang dikeluarkan dalam usaha agroindustri dodol kentang Lubuk Nagodang berasal dari biaya variabel yaitu sebesar Rp. 2.233.035 (99,75\%). Berdasarkan hasil penelitian Tresnawati (2010) besarnya biaya variabel disebabkan komposisi biaya variabel lebih banyak dibandingkan dengan komposisi biaya tetap sehingga biaya variabel yang dikeluarkan lebih besar. Selain itu juga disebabkan karena tingginya harga bahan produksi untuk proses produksi dodol kentang Lubuk Nagodang. Sedangkan rata-rata biaya tetap yang terdiri dari biaya penyusutan peralatan dikeluarkan Rp. 5.580 (0,25\%). Keuntungan yang diperoleh agroindustri dodol kentang Lubuk Nagodang merupakan selisih antara penerimaan dengan total biaya yang dikeluarkan dalam satu kali proses produksi, dapat dilihat pada Tabel 2.

Tabel 2. Keuntungan Usaha Agroindustri Dodol kentang Lubuk Nagodang di Kabupaten Kerinci Dalam Satu Kali Produksi

\begin{tabular}{llr}
\hline No & Uraian & Rata-Rata (Rp) \\
\hline 1 & Penerimaan & 5.864 .000
\end{tabular}


ISSN: $1412-8241$ (p); 2621-1246 (e), Volume 21. no (1) 2018

DOI: $10.22437 / j i s e b . v 21 i 1$

2 Biaya Total

2.238 .615

Keuntungan

3.625 .385

Berdasarkan penelitian Tresnawati (2010) besarnya penerimaan dipengaruhi oleh jumlah produk yang diproduksi oleh setiap pengrajin, yaitu semakin banyak jumlah produk yang diproduksi maka akan semakin besar pula penerimaan. Pada tabel tersebut dapat dilihat bahwa besarnya rata-rata keuntungan untuk satu kali proses produksi sebesar Rp. 3.625.385. Dibandingkan dengan penelitian Mea (2014) memperoleh keuntungan yang besar yaitu Rp. 9.407.350 dalam 4 minggu produksi maka agroindustri dodol kentang Lubuk Nagodang termasuk agroindustri yang memperoleh keuntungan yang besar untuk satu kali produksi. Besar kecilnya keuntungan usaha agroindustri tergantung dengan bersar kecilnya penerimaan dan biaya yang dikeluarkan oleh agroindustri.

\section{Analisis SWOT}

Berdasarkan hasil penelitian melalui analisis SWOT dapat diketahui potensi agroindustri dodol kentang Lubuk Nagodang. Analisis SWOT ini dilakukan dengan mengidentifikasi lingkungan internal dan eksternalanya terlebih dahulu. Dimana lingkungan internal dan eksternal ini terdapar empat unsur yaitu, kekuatan (strenght), kelemahan (weaknesses), peluang (opportunities), ancaman (threats).

\section{Identifikasi Lingkungan Internal dan Lingkungan Eksternal}

Berdasarkan hasil analisis lingkungan internal dan eksternal maka dapat diidentifikasikan kekuatan (strengths), kelemahan (weaknesses), peluang (opportunities) dan ancaman (threats) yang berpengaruh terhadap pengembangan usaha agroindustri dodol kentang Lubuk Nagodang di Kabupaten Kerinci. Hasil identifikasi lingkungan internal dan eksternal dari adalah sebagai berikut : 1) kekuatan (Strengths), menurut Kuncoro (2006) kekuatan merupakan kompetisi khusus yang terdapat didalam organisasi yang berakibatkan pada kepemilikan keunggulan komperatif oleh unit usaha yang dipasarkan. Kekuatan dari agroindustri dodol kentang Lubuk Nagodang adalah sebagai berikut : a) lokasi usaha yang strategis, b ) lebih modal sendiri, c) sistem upah borongan, d) tenaga kerja yang berpengalaman, e) tenaga kerja berasal dari luar keluaraga, f) memiliki perizinan produk, g) bahan baku dan bahan penolong yang tersedia, h) bahan baku dan bahan penolong memenuhi kapasitas produksi dodol kentang Lubuk Nagodang, i) produksi menggunakan teknologi mekanik, 2) Kelemahan (Weaknesses), menurut Kuncoro (2006) Kelemahan merupakan keterbatasa atau kekurangan dalam hal sumber keterampilan dan kemampuan yang menjadi penghalang serius bagi penampilan kerja organisasi yang memuaskan, yang menjadi kelemahan pada pengembangan agroindustri dodol kentang Lubuk Nagodang adalah: a) lemahnya promosi, b) ketahanan produk relatif singkat, c) manajemen yang kurang baik, d) pengemasan menggunakan teknologi manual, 3) Peluang (Opportunities), peluang merupakan situas faktor eksternal yang membantu perusahaan mencapai atau bahkan melampaui pencapaian sasarannya.

Peluang yang dimiliki oleh agroindustri dodol kentang Lubuk Nagodang adalah : a) volume permintaan pasar meningkat, b) harga permintaan pasar stabil, c) adanya bantuan pemerintah, d) jumlah produk yang dipasarkan meningkat, e) tujuan pemasaran produk dodol kentang Lubuk Nagodang Kabupaten Kerinci telah sampai di Kab. Kerinci, Kab. Merangin, Kab. Muara Jambi, Kota Sungai Penuh, Prov. Sumbar, dan Kep. Riau, f) kontinuitas produk terjaga, g) ditunjang dengan adanya 4 lembaga yang dapat meminjamkan modal usaha (Bank, KUD, KUPEM dan PNPM). (3) Acaman (Threats), ancaman merupakan faktor eksternal yang menyebabkan tidak daat mencapai sasarannya. Ancaman yang terdapat pada agroindustri dodol kentang Lubuk Nagodang adalah : a) 


\section{JURNAL ILMIAH SOSIO-EKONOMIKA BISNIS}

ISSN: 1412-8241 (p); 2621-1246 (e), Volume 21. no (1) 2018

DOI: 10.22437 jiseb.v21i1

adanya pesaing produk sejenis, b) adanya pesaing produk substitusi yang dipasarkan di Kabupaten Kerinci, c) akses dalam memperoleh bantuan usaha dari kelembagaan yang sulit.

\section{Penentuan Posisi}

Penentuan posisi dilakukan dengan penentuan nilai bobot, penentuan nilai rating, matriks IFAS dan EFAS serta diagram analisis SWOT. Pada Tabel 3 dapat dilihat hasil pengalian nilai bobot dan rating sehingga diperoleh skor untuk masing-masing faktor.

Tabel 3. Matrik IFAS dan EFAS Agroindustri Dodol kentang Lubuk Nagodang di Kabupaten Kerinci

\begin{tabular}{|c|c|c|c|c|}
\hline & Faktor Kunci & Bobot & Rating & Skor \\
\hline \multicolumn{5}{|c|}{ Kekuatan } \\
\hline 1 & Lokasi usaha strategis & 0,08 & 3,8 & 0,30 \\
\hline 2 & Modal Sendiri & 0,08 & 3,4 & 0,27 \\
\hline 3 & sistem upah tenaga kerja borongan & 0,07 & 2,6 & 0,18 \\
\hline 4 & Tenaga kerja berpengalaman & 0,07 & 2,4 & 0,17 \\
\hline 5 & Sumber tenaga kerja dari luar keluarga & 0,08 & 2,2 & 0,18 \\
\hline 6 & memiliki perizinan produk & 0,09 & 3,2 & 0,29 \\
\hline 7 & bahan baku dan bahan penolong selalu tersedian & 0,06 & 3,8 & 0,23 \\
\hline 8 & bahan baku dan bahan penolong memenuhi kapasitas produksi & 0,06 & 3,2 & 0,19 \\
\hline \multirow[t]{3}{*}{9} & menggunakan teknologi produksi mekanik & 0,06 & 2,2 & 0,13 \\
\hline & Total & 0,65 & & 1,94 \\
\hline & Rata-rata & & & 0,21 \\
\hline \multicolumn{5}{|c|}{ Kelemahan } \\
\hline 10 & Lemahnya Promosi & 0,08 & 1,8 & 0,14 \\
\hline 11 & Ketahanan produk relatif singkat dan mudah ditiru & 0,08 & 1,6 & 0,13 \\
\hline 12 & kemasan masih sederhana & 0,06 & 2,2 & 0,13 \\
\hline 13 & rendahnya keterampilan manajerial & 0,05 & 2 & 0,10 \\
\hline \multirow[t]{3}{*}{14} & Teknologi pengemasan manual & 0,06 & 2,8 & 0,17 \\
\hline & Total & 0,33 & & 0,67 \\
\hline & Rata-rata & & & 0,13 \\
\hline \multicolumn{5}{|c|}{ Peluang } \\
\hline 1 & Volume permintaan pasar meningkat & 0,09 & 1,6 & 0,14 \\
\hline 2 & harga prmintaan pasa stabil & 0,10 & 3,4 & 0,34 \\
\hline 3 & adanya bantuan pemerintah & 0,10 & 3,6 & 0,36 \\
\hline 4 & jumlah produk meningkat & 0,09 & 1,6 & 0,14 \\
\hline 5 & tujuan pemasaran di Kab. Kerinci dan luar kabupaten kerinci & 0,09 & 3,8 & 0,34 \\
\hline 6 & $\begin{array}{l}\text { dodol kentang Lubuk Nagodang memiliki kekhasan dari segi } \\
\text { rasa, tekstur dan penampilah produk }\end{array}$ & 0,08 & 3,8 & 0,30 \\
\hline 7 & kontinuitas produk terjaga & 0,08 & 3,2 & 0,26 \\
\hline \multirow[t]{3}{*}{8} & $\begin{array}{l}\text { ditunjang dg adanya } 4 \text { kelembagaan yang menunjang proses } \\
\text { produksi }\end{array}$ & 0,09 & 3 & 0,27 \\
\hline & Total & 0,72 & & 2,16 \\
\hline & Rata-rata & & & 0,27 \\
\hline \multicolumn{5}{|c|}{ Ancaman } \\
\hline 9 & adanya pesaing sejenis & 0,10 & 1,2 & 0,12 \\
\hline 10 & adanya pesaung substitusi & 0,10 & 1,8 & 0,18 \\
\hline \multirow[t]{3}{*}{11} & $\begin{array}{l}\text { askes dalam memproses bantuan usaha dan kelembagaan yang } \\
\text { sulit }\end{array}$ & 0,08 & 1,2 & 0,10 \\
\hline & Total & 0,28 & & 0,40 \\
\hline & Rata-rata & & & 0,13 \\
\hline
\end{tabular}




\section{JURNAL ILMIAH SOSIO-EKONOMIKA BISNIS}

ISSN: 1412-8241 (p); 2621-1246 (e), Volume 21. no (1) 2018

DOI: $10.22437 / j i s e b . v 21 i 1$

Melalui skor tersebut dapat dilihat pada matriks IFAS bahwa yang menjadi kekuatan utama pada agroindustri dodol kentang Lubuk Nagodang adalah lokasi usaha yang strategis dengan skor tertinggi 0,30. Lokasi usaha agroindustri dodol kentang Lubuk Nagodang terletak di jalan raya Desa Lubuk Nagodang Kecamatan Siulak, dikatakan strategis karena merupakan jalan lintas provinsi, dekat dengan bahan baku, sarana dan prasarana angkutan, dan pada saat ini desa ini telah dikenal dengan pusat oleh-oleh Kabupaten Kerinci. Pada matrik IFAS yang menjadi kelemahan utama pada agroindustri ini dengan skor terendah 0,10 adalah rendahnya keterampilan manajerial dalam pengelolaan usaha dodol kentang Lubuk Nagodang. Manajemen sangat dibutuhkan dalam suatu usaha, hal ini bertujuan untuk menentukan apakah suatu usaha mampu bergerak secara efisien, efektif dan produktif untuk mencapai tujuan dan sasaran yang telah ditetapkan sebelumnya. Rendahnya keterampilan manajerial dalam pengelolaan usaha dodol kentang Lubuk Nagodang disebabkan kurangnya diterapkan aturan tegas terahadap tenaga kerja terkait kedisiplinan kerja karena pada dasarnya sistem perekrutan tenaga kerja yang dilakukan secara sederhana dan kekeluargaan dan tidak diterapnya pembukuan produk.

Melalui matriks EFAS yang menjadi peluang utama yang dapat dimanfaatkan oleh agroindustri ini yang terlihat pada matriks EFAS adalah adanya bantuan pemerintah yang sangat mendukung dan adanya 4 kelembagaan (KUD, KUPEM, PNPM dan Bank) yang menunjang proses produksi dengan skor 0,36 . Ini merupakan peluang yang sangat bagus untuk pengembangan agroindustri, karena Pemerintah Kabupaten Kerinci memiliki perhatian yang khusus terhadap usaha agroindustri dodol kentang Lubuk Nagodang. Pada matrik EFAS yang menjadi ancaman utama yang harus diantisipasi oleh agroindustri dodol kentang Lubuk Nagodang dengan skor terendah 0,10 yaitu sulitnya akses dalam memperoleh bantuan.

Langkah selanjutnya untuk menentukan posisi agroindustri dodol kentang Lubuk Nagodang di Kabupaten Kerinci. Melalui selisih nilai tertimbang dari masing-masing kategori pada matriks IFAS dan EFAS akan didapat nilai titik kuadran yang akan menentukan posisi agroindustri dodol kentang Lubuk Nagodang pada diagram analisis SWOT dilakukan dengan cara mengurangi masing-masing nilai tertimbang dari faktor strategi kekuatan dan kelemahan dan pengurangan nilai tertimbang dari faktor strategis peluang dan ancaman. Dari matriks IFAS dan EFAS diatas dapat dilihat nilai rata-rata tertimbang faktor strategis kekuatan adalah 0,21 , jika dikurangi dengan nilai tertimbangn faktor strategis kelemahan 0,13 maka diperoleh titik kuadran pertama yaitu 0,08 , nilai tertimbang faktor strategis faktor strategis peluang yaitu 0,27 dikurangi faktor strategis ancaman yaitu 0,13, maka diperoleh titik kuadran yang kedua yaitu 0,14 , melalui hasil selisih tertimbang tersebut maka dapat posisit agroindustri dodol kentang Lubuk Nagodang di Kabupaten Kerinci pada diagram analisis SWOT (Gambar 1) berikut :

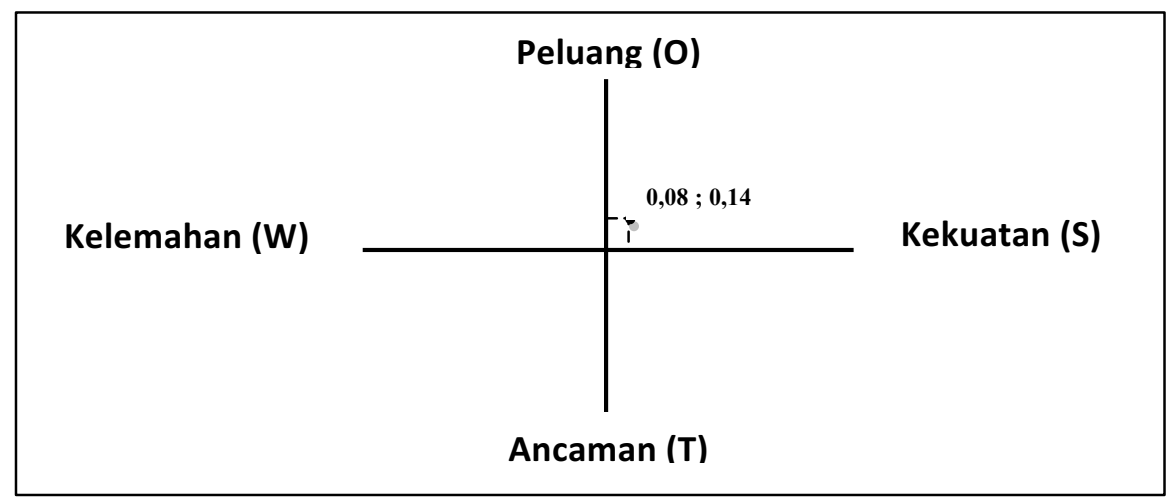




\section{JURNAL ILMIAH SOSIO-EKONOMIKA BISNIS}

ISSN: 1412-8241 (p); 2621-1246 (e), Volume 21. no (1) 2018

DOI: $10.22437 / j i s e b . v 21 i 1$

\section{Gambar 1. Diagram analisis SWOT Agroindustri Dodol Kentang Lubuk Nagodang di} Kabupaten Kerinci

Berdasarkan diagram analisis SWOT pada Gambar 1 diatas dapat dilihat posisi dari agroindustri dodol kentang Lubuk Nagodang di Kabupaten Kerinci terletak pada kuadran I yang merupakan situasi yang sangat menguntungkan. Agroindustri ini memiliki kekuatan dan peluang yang dapat dimanfaatkan, adapun strategi yang harus diterapkan dalam kondisi menurut Rangkuti (2015) adalah medukung kebijakan pertumbuhan yang agresif (growth oriented strategy) atau strategi agresif (aggressive strategy). Berdasarkan hasil penelitian Ismaya (2015) kuadran I menunjukkan bahwa memanfaatkan atau merebut peluang yang ada secara optimal, dengan memaksimalkan kekuatan yang dimiliki. Agroindustri ini bersifat agresif, dalam kondisi yang baik untuk terus diusahakan dan dikembangkan dengan melihat kekuatan yang ada dan melakukannya dengan memanfaatkan peluang-peluang yang tesedia. Dengan menggunakan indikator lingkungan internal dan lingkungan eksternal tersebut, maka perlu dilakukan perumusan alternatifalternatif menggunakan matriks SWOT.

\section{Alternatif Strategi Agroindustri Dodol kentang Lubuk Nagodang di Kabupaten Kerinci}

Analisis terhadap lingkungan memperlihatkan bahwa agrindustri dodol kentag di Kabupaten Kerinci dalam menjalan kan produksi sangat dipengaruhi oleh faktor lingkungan internal seperti : lokasi, modal, tenaga Kerja, manajemen, bahan baku dan bahan penolong, dan teknologi. Agroindustri juga dipengaruhi oleh faktor lingkungan eksternal seperti : permintaan pasar, pesaing, bantuan pemerintah, pemasaran hasil produk dan lembaga pemberi pinjaman. Berdasarkan hasil analisis matriks IFAS dan EFAS dapat diketahui posisi agroindustri dodol kentang Lubuk Nagodang di Kabupaten Kerinci, terletak pada kuadran I dengan titik kuadran $(0,08 ; 0,14)$ dan strategi yang harus diterapkan adalah strategi agresif. Berdasarkan matriks SWOT didapatkan strategi SO dimana menurut Rangkuti (2015) untuk menciptakan strategi yang menggunakan kekuatan untuk memanfaatkan peluang. Suatu usaha agar berdaya saing tinggi harus memiliki strategi tersebut sesuai dengan posisi dan kemampuan usaha saat ini sehingga pengembangan usaha dapat lebih efektif.

Hasil dari matriks IFAS dan EFAS selanjutnya diformulasikan kedalam matriks SWOT. Pemformulasi faktor aktif strategi dalam analisis SWOT. Adapun alternatif strategi yang dapat dilakukan dalam pengembangan agroindustri dodol kentang Lubuk Nagodang di Kabupaten Kerinci adalah sebagai beikut : 1) Bekerjasama dengan pemerintah dalam pengembangan agroindustri dodol kentang Lubuk Nagodang. Melakukan kerjasama dengan pihak pemerintah untuk mengembangkan produk dan promosi secara efektif dan meluas dalam rangka perluasan pasar. Pemanfaatan bantuan peralatan secara optimal juga perlu dilakukan untuk meningkatkan kualitas produk. Sejalan dengan penelitian Ismaya (2015), bermitra dengan pemerintah merupakan peluang bagi pengrajin agroindustri untuk mempromosikan produknya karena pemerintah sering adanya kunjungan oleh tamu-tamu baik dari lur maupun dalam daerah untuk membeli produk asli daerah, 2) meningkatkan kualitas, kuantitas dan memperluas pangsa pasar produksi dodol kentang Lubuk Nagodang melalui peningkatan kemampuan teknis tenaga kerja dan kerja sama dengan pemasok bahan baku kentang.

Dalam pengembangan usaha agroindustri dodol kentang Lubuk Nagodang di kabupaten diperlukan adanya upaya peningkatan kualitas dan sumber daya manusia (SDM) yang ada yaitu dengan cara memberikan penyuluhan dan pelatihan. Pemerintah harus terus meningkatkan peranannya dalam menyediakan sarana pelatihan. Melalui kegiatan pelatihan yang diberikan akan meningkatkan kemampuan teknis tenaga kerja dan terciptanya prosedur kerja serta pengelolaan usaha yang baik. Sehingga, hal tersebut dapat 


\section{JURNAL ILMIAH SOSIO-EKONOMIKA BISNIS}

ISSN: 1412-8241 (p); 2621-1246 (e), Volume 21. no (1) 2018

DOI: 10.22437 jiseb.v21i1

mendukung selalu terjaganya kualitas dan kontinuitas produksi dengan baik karena adanya kesadaran tentang pentingnya prosedur kerja yang baik dengan memperhatikan proses produksi yang tepat dan sesuai.

Selain itu untuk dapat mempertahankan eksistensi usaha, dalam pengembangan usaha agroindustri dodol kentang Lubuk Nagodang di Kabupaten Kerinci juga perlu didukung dengan terjalinnya kerjasama yang baik dengan pemasok bahan baku. Berdasarkan penelitian Tresnawati (2010) juga menyatakan bahwa dengan terjalinnya kerjasama yang baik maka kebutuhan akan bahan baku kentang dapat terus tersedia sehingga kontinuitas produksi dapat terjaga dan pengrajin dapat memenuhi permintaan yang meningkat terutama pada saat perayaan hari besar karena gaya hidup masyakat yang menyukai membawa oleh-oleh untuk sanak saudaranya. Peluasan pangsa pasar didukung dengan adanya kekuatan tenaga kerja berpengamalan dan penggunaan teknologi mekanikmanual terjaminnya ketersediaan bahan baku. Selain itu, didukung dengan pemasaran masih terbatas. Adanya peluang tersebut diharapkan dapat mengembangkan agroindustri dodol kentang Lubuk Nagodang yaitu dengan strategi perluasan jangkauan pangsa pasar diluar Provinsi Jambi.

Perluasan jangkauan pasar yaitu dengan pengenalan produk ke wilayah baru. Wilayah baru adalah wilayah yang belum mengenal dodol kentang Lubuk Nagodang atau wilayah yang sudah mengenal dodol kentang Lubuk Nagodang, tetapi belum menjadi lokasi pemasaran pengrajin. Dodol kentang Lubuk Nagodang selama ini masih sebagian besar masih dipasarkan dalam lingkup Provinsi Jambi dan Provinsi Sumatera Barat itupun hanya beberapa pengrajin yang memasarkan diluar provinsi. Berdasarkan hasil penelitian Sundari (2012) bahwa perluasan cakupan pasar dapat berjalan dengan baik apabila ketersediaan produk terjamin. Strategi ini diharapkan dapat memperluas cakupan pasar keseluruh pulau di Indonesia, 3) memodifikasi kemasan untuk dapat meningkatkan daya tarik produk. Banyaknya pesaing produk yang mengolah bahan baku yang sama. Banyaknya pesaing produk yang mengolah bahan baku yang sama. Salah satu cara meningkatkan pengembangan agroindustri dodol kentang Lubuk Nagodang dengan melakukan perbaikan inovasi kemasan dodol kentang Lubuk Nagodang, walaupun telah memiliki berbagai variasi ukuran namun untuk kemasan dapat dimodifikasi dengan memberi label informasi merek dagang pada kemasan plastik pembungkus dan pada label diberikan informasi rasa dari dodol kentang Lubuk Nagodang. Selain itu menciptakan dodol kentang Lubuk Nagodang dalam kemasan baru, variasi kotak kemasan yang memberikan informasi yang jelas kepada konsumen. Sesuai dengan penelitian Mea (2012), modifikasi kemasan merupakn suatu upaya untuk peningkatan suatu agroindustri dengan cara menciptakan inovasi baik dari pilihan rasa sehingga segmen konsumen menjadi lebih beragam maupun dengan inovasi kemasan.

\section{KESIMPULAN}

Berdasarkan hasil penelitian mengenai strategi pengembangan agroindustri dodol kentang Lubuk Nagodang di Kabupaten Kerinci dapat diambil beberapa kesimpulan. Penerimaan yang diperoleh pengrajin dodol kentang Lubuk Nagodang di Kabupaten Kerinci dalam satu kali produksi adalah sebesar Rp. 5.864.000 dengan biaya total yang dikeluarkan sebesar Rp. 2.238.615 sehingga keuntungan yang diperoleh pengrajin dodol kentang Lubuk Nagodang di Kabupaten Kerinci adalah sebesar Rp. 3.625.385 yang berarti pengrajin dodol kentang Lubuk Nagodang di Kabupaten Kerinci memperoleh keuntungan yang besar.

Agroindustri dodol kentang Lubuk Nagodang merupakan industri kecil dengan jumlah tenaga kerja 5-19 orang. Faktor-faktor internal (kekuatan dan kelemahan) dan eksternal (peluang dan ancaman) pengembangan agroindustri dodol kentang Lubuk Nagodang di 


\section{JURNAL ILMIAH SOSIO-EKONOMIKA BISNIS}

ISSN: 1412-8241 (p); 2621-1246 (e), Volume 21. no (1) 2018

DOI: 10.22437/jiseb.v21i1

Kabupaten Kerinci adalah sebagai berikut : 1) Kekuatan : lokasi usaha yang strategis, lebih modal sendiri, sistem upah borongan, tenaga kerja yang berpengalaman, tenaga kerja berasal dari luar keluaraga, memiliki perizinan produk, ketersediaan bahan baku dan bahan penolong memenuhi kapasitas produksi dodol kentang Lubuk Nagodang, menggunakan teknologi mekanik, 2) Kelemahan: lemahnya promosi,ketahanan produk relatif singkat, manajemen yang kurang baik, pengemasan menggunakan teknologi manual, 3) Peluang : volume permintaan pasar meningkat, harga permintaan pasar stabil, adanya bantuan pemerintah, jumlah produk yang dipasarkan meningkat, tujuan pemasaran produk dodol kentang Lubuk Nagodang Kabupaten Kerinci telah sampai di Kab. Kerinci, Kab. Merangin, Kab. Muara Jambi, Kota Sungai Penuh, Prov. Sumbar, dan Kep. Riau, kontinuitas produk terjaga, ditunjang dengan adanya 4 lembaga yang dapat meminjamkan modal usaha (Bank, KUD, KUPEM dan PNPM), 4) Acaman: adanya pesaing produk sejenis, adanya pesaing produk substitusi yang dipasarkan di Kabupaten Kerinci, akses dalam memperoleh bantuan usaha dari kelembagaan yang sulit.

Agroindustri dodol kentang Lubuk Nagodang berada pada kuadran I dan strategi yang dapat diterapkan pada posisi ini adalah mendukung kebijakan pertumbuhan yang agresif (growth oriented strategy) atau strategi agresif (aggressive strategi). Alternatif strategi yang dapat diterapkan dalam upaya pengembangan agroindustri dodol kentang Lubuk Nagodang di Kabupaten Kerinci adalah Strategi S-O (Strenght-Opportunities) diantaranya : a) bekerjasama dengan pemerintah dalam pengembangan agroindustri dodol kentang Lubuk Nagodang, b) meningkatkan kualitas, kuantitas dan memperluas pangsa pasar produksi dodol kentang Lubuk Nagodang melalui peningkatan kemampuan teknis tenaga kerja dan kerja sama dengan pemasok bahan baku kentang, c) memodifikasi kemasan untuk dapat meningkatkan daya tarik produk

\section{UCAPAN TERIMA KASIH}

Pada kesempatan kali ini penulis menyampaikan ucapan terima kasih kepada Dekan Fakultas Pertanian dan Ketua Jurusan Agribisnis Fakultas Pertanian Universitas Jambi yang telah memfasilitasi pelaksanaan penelitian ini. Ucapan terimakasih kepada pembimbing akademik selaku pembimbing skripsi I dan pembimbing Skripsi II yang telah membimbing dan memberikan arahan dalam proses penyusunan skripsi. Selain itu ucapan terima kepada pengrajin agroindustri dodol kentang Lubuk Nagodang, pemilik mini market dan toko makanan ringan serta Dinas Perindustrian, Perdagangan dan ESDM Kabupaten Kerinci, yang bersedian menjadi responden dalam penelitian ini. Ucapan terimakasih dihaturkan juga Badan Kesatuan Bangsa dan Politik Kabupaten Kerinci, Kepala Desa dan Sekretaris Desa Lubuk Nagodang yang telah memfasilitasi penelitian di lapangan.

\section{DAFTAR PUSTAKA}

Ismaya, Resty. 2015. Analisis Strategi Pengembangan Agroindustri Sirup Kulit Manis Kabupaten Kerinci. Skripsi Fakultas Pertanian Universitas Jambi. ( Tidak Dipublikasikan).

Kuncoro, Mudrajad. 2006. Metode Riset untuk Bisnis \& Ekonomi. Erlangga. Jakarta.

Mea, Chelsy. 2012. Analisis Usaha dan Strategi Pengembangan Agroindustri Manisan Pala di Kelurahan Aermadidi Kabupaten Minahasa Utara (Studi Kasus di UD Murni). Skripsi Fakultas Pertanian Universitas Sam Ratulangi. Manado. Diunduh dari www.digilid.USR.ac.id. (diakses 28 Desember 2015). 


\section{JURNAL ILMIAH SOSIO-EKONOMIKA BISNIS}

ISSN: 1412-8241 (p); 2621-1246 (e), Volume 21. no (1) 2018

DOI: 10.22437/jiseb.v21i1

Rangkuti, F. 2015. Teknik Membedah Kasus Bisnis Analisis SWOT. PT. Gramedia Pustaka Utama. Jakarta.

Sukirno, Sadono. 2015. Pengantar Teori Mikro ekonomi. Edisi Ketiga. PT. Raja Grafindo Persada. Jakarta.

Sundari, Firnika SF. 2012. Strategi Pengembangan Agroindustri Grubi Ketela Ungu di Kecamatan Tawangmangu Kabupaten Karanganyar. Skripsi Fakultas Pertanian Universitas Sebelas Maret. Surakarta. Diunduh dari www.digilib.uns.ac.id. (diakses 15 Januari 2016).

Soekartawi. 2005. Agribisnis (Teori dan Aplikasinya). PT Raja Grafindo Persada, Jakarta.

Soekartawi. 2001. Pengantar Agroindustri. PT Raja Grafindo Persada. Jakarta.

Tjipjono, fandi. 2002. Strategi Pemasaran. CV. Andi Offset. Yogyakarta.

Tresnawati. Dinar. 2010. Analisis Pengembangan Agroindustri Dodol Nanas di Kabupaten Subang. Skripsi Fakultas Pertanian Universitas Sebelas Maret. Surakarta. Diunduh dari http://Perpustakaan.uns.ac.id. (diakses 20 Oktober 2015). 